\title{
PENGEMBANGAN MEDIA POCKET BOOK BERBASIS DISCOVERY LEARNING TERHADAP KEMAMPUAN PEMAHAMAN MATEMATIS
}

\author{
Dea Armelia ${ }^{1}$, Iwit Prihatin ${ }^{2}$, Utin Desy Susiaty ${ }^{3}$ \\ Program Studi Pendidikan Matematika, IKIP PGRI Pontianak ${ }^{1,2,3}$ \\ d3or4f4ty4@gmail.com
}

\begin{abstract}
Abstrak
Tujuan penelitian dalam penelitian adalah untuk mengetahui pengembangan media pocketbook berbasis discovery learning terhadap kemampuan pemahaman matematis siswa. Metode penelitian dan pengembangan (R\&D) adalah metodologi dalam penelitian ini. Berdasarkan hasil pengembangan, penelitian, dan pembahasan dapat disimpulkan bahwa pengembangan media pocket book berbasis discovery learning terhadap kemampuan pemahaman matematis mencapai tingkat kevalidan dengan kategori sangat baik dan mencapai tingkat kepraktisan dengan kriteria sangat praktis.
\end{abstract}

Kata Kunci: media, pocket book, kemampuan pemahaman matematis

\begin{abstract}
Abstact
The purpose of the research in the study was to study the development of learning discovery-based pocket book media on students' mathematical understanding abilities. The research methodology used is the method of research and development $(R \& D)$. Based on the results of development, research, and discussion, it can be concluded that the development of learning discovery-based pocket book media on mathematical understanding skills reaches a level of validity with excellent categories and achieves practicality with very practical criteria.
\end{abstract}

Keywords: media, pocket books, mathematical understanding skills

\section{PENDAHULUAN}

Ilmu yang mendasari perkembangan teknologi modern adalah matematika, dimana mempunyai peranan yng sangat penting dalam berbagai disiplin ilmu serta dapat mengembangkan daya pikir manusia Tujuan dipelajarinya matematika yaitu sebagai berikut: (1) pemahaman konsep matematika, penjelelasan keterkaitan antarkonsep dan dapat mengaplikasikan konsep atau algoritma secara luwes, akurat, efisien, serta tepat dalam pemecahan masalah, (2) penggunaan penalaran pada pola dan sifat, sehingga dapat membuat generalisasi secara umum dengan melakukan manipulasi matematika, menyusun bukti, atau menjelaskan gagasan dan pernyataan matematika, kemampuan memahami masalah, merancang model matematika, menyelesaikan model dan menafsirkan solusi yang diperoleh merupakan cakupan dari pemecahan masalah, (4) pengkomunikasian gagasan dalam bentuk simbol, tabel, diagram, atau media lain untuk memperjelas keadaan atau masalah, (5) rasa ingin tahu, perhatian, dan minat dalam mempelajari matematika, serta sikap ulet dan percaya diri dalam pemecahan masalah merupakan sikap yang harus dimiliki dalam menghargai manfaat adanya matematika dalam kehidupan sehari-hari. Karena itulah, sangat jelas bahwa poin pertama kemampuan yang harus dimiliki oleh siswa adalah kompetensi yang disebut dengan kemampuan pemahaman matematis siswa dalam pembelajaran matematika.

Kompetensi dasar dalam belajar matematika yang meliputi: konsep yang telah dipelajari dinyatakan ulang, konsep yang dibentuk diklarifikasi berdasarkan dipenuhi atau tidaknya persyaratan dari objek-objek tersebut, sifat-sifat operasi atau konsep diidentifikasi, menerapkan konsep secara logis, konsep yang telah dipelajari diberikan contoh atau bukan contoh, bentuk representasi matematis (tabel, grafik, diagram, gambar, sketsa, model matematika 
atau cara lainnya) merupakan berbagai macam penyajian konsep, berbagai konsep dalam matematika maupun di luar matematika saling dikaitkan, mengembangkan syarat perlu atau syarat cukup suatu konsep merupakan kemampuan pemahaman matematis [1].

Keberhasilan pencapaian pemahaman matematis siswa sangat dipengaruhi oleh peran guru dalam menyampaikan materi. Salah satu contohnya yaitu pada materi aritmatika sosial di kelas VII SMP. Kurang tepatnya pemilihan strategi pembelajaran dan keterbatasan guru dalam penggunaan media dalam proses pembelajaran di kelas merupakan salah satu factor terciptanya kondisi dimana tidak tercapainya keberhasilan kemampuan pemahaman matematis siswa yang diharapkan. Dari hasil pra observasi peneliti kepada siswa kelas VIII MTs Hidayatul Muhsinin diperoleh hasil siswa tersebut masih mengalami kurangnya kemampuan pemahaman matematis pada materi aritmetika sosial. Hal tersebut dibuktikan oleh guru mata pelajaran matematika berdasarkan hasil wawancara terhadap guru tersebut diperoleh bahwa kemampuan pemahaman matematis siswanya dalam penyelesaian soal matematika masih kurang, dimana sebagian siswa hanya mampu menghafal rumus-rumus dan belum memahami konsep dari matematika itu sendiri dengan benar. Hal tersebut ditunjukkan oleh siswa hanya mampu mengerjakan soal yang sama persis dengan contoh soal yang diberikan oleh guru, terlebih lagi soal yang berbentuk cerita, seperti pada materi aritmetika sosial kelas VII. Siswa juga masih belum memahami dalam mengaitkan antar konsep pada materi tersebut yang mengakibatkan kesulitan dalam menyelesaikan permasalahan.

Selain itu, fakta lain yang didapat melalui kegiatan wawancara tersebut adalah strategi pembelajaran yang diterapkan oleh guru pelajaran matematika tersebut dalam pembelajaran masih konvensional dan belum pernah menerapkan strategi pembelajaran yang sesuai dengan penerapan kurikulum 2013. Sehingga dengan kenyataan yang ada guru tersebut belum dapat terlepas dari kurikulum sebelumnya dan belum mengedepankan student oriented dalam proses pembelajaran. [2] menyatakan bahwa peserta didik hanya menerima apa yang disampaikan oleh guru, tanpa dilibatkan dalam kegiatan yang dapat mengkostruk pengetahuan yang harus mereka peroleh, pada akhirnya pengetahuan yang diperoleh peserta didik tidak bertahan lama dalam ingatan mereka. [3] juga mengatakan bahwa dalam mempelajari matematika siswa harus memahami konsep matematika terlebih dahulu agar dapat menyelesaikan soal-soal dan mengaplikasikan masalah-masalah dalam dunia nyata yang diartikan sebagai penekanan konsep pada mata pelajaran matematika.

Salah satunya strategi pembelajaran yang baru-baru ini digunakan dalam penerapan kurikulum 2013 dengan pendekatan saintifik adalah discovery learning. Menurut Budiningsih (dalam [3]), discovery learning merupakan suatu pembelajaran penemuan, dimana konsep, arti, dan hubungan melalui proses intuitif untuk akhirnya sampai kepada kesimpulan dipahami sendiri oleh peserta didik. Berarti dengan pembelajaran menggunakan pendekatan saintifik melalui discovery learning akan mengembangkan kemampuan pemahaman matematis peserta didik dalam pembelajaran, karena peserta didik menemukan sendiri suatu teori melalui pengalaman ilmiah, mengkonstruksi konsep, hukum atau prinsip melalui pendekatan saintifik, yang meliputi kegiatan mengamati, menanya, mencoba, mengolah, hingga mengkomunikasikan. 
Selain tepatnya strategi pembelajaran yang dipilih, keberadaan media juga dapat berpengaruh terhadap peningkatan pemahaman matematis siswa. Pendidikan telah dipengaruhi oleh keseluruhan sejarah, media dan teknologi (Henick dkk, dalam [4]). Dengan demikian, peran yang sangat penting terletak pada penggunaan media dalam proses belajar mengajar karena media sebagai alat perantara menyampaikan informasi atau bahan pelajaran dan sangat berpengaruh dalam kegiatan belajar mengajar.

Dari uraian dan fakta di atas, maka keperluan untuk melakukan penelitian yang berfokus pada pengembangan media pembelajaran dengan strategi discovery learning untuk mengembangkan kemampuan pemahaman matematis peserta didik, merupakan langkah yang sangat perlu dan utama. Dengan demikian, penulis memilih media gambar berbentuk buku atau media cetak yang dikembangkan dalam bentuk pocket book atau buku saku. [5] menyatakan bahwa Pocket book atau buku saku merupakan salah satu bentuk media pembelajaran cetak yang bentuknya hampir sama dengan booklet, hanya saja pocket book ini didesain berukuran lebih kecil dan praktis sehingga bisa dibawa kemana-mana. Pocket book ini dirancang sedemikian rupa dengan variasi gambar, huruf dan warna yang membuat siswa termotivasi untuk membacanya dan merangsang kemampuan siswa mengeluarkan gagasan atau ide yang dimiliki. Melaui penelitian R\&D yang berjudul Pengembangan Media Pocket Book Berbasis Discovery Learning Terhadap Kemampuan Pemahaman Matematis Pada Materi Aritmetika Sosial kelas VII MTs Hidayatul Muhsinin Kabupaten Kubu Raya diharapkan mampu membantu siswa untuk memiliki pemahaman matematis dalam materi aritmetika sosial yang disampaikan dan guru mendapatkan media baru yang bertujuan untuk mencapai kriteria ketuntasan yang ditentukan.

\section{METODE}

Metode Research and Development (R\&D) adalah metode penelitian yang digunakan dalam penelitian ini atau biasa disebut dengan metode penelitian dan pengembangan. [6] mengatakan bahwa untuk menghasilkan produk tertentu, dan menguji keefektifan produk tersebut digunakanlah metode penelitian dan pengembangan. Rancangan penelitian dan pengembangan dalam $R \& D$ ini menggunakan model pengembangan 4-D yang dikembangkan oleh S. Thiagarajan, Dorothy S. Semmel, dan Melvyn I. Semmel. Pengembangan 4-D terdiri atas 4 tahap utama, yaitu: define, design, develop dan desseminate.

Sesuai dengan kebutuhan peneliti, tahapan yang dilakukan dalam penelitian ini hanya terdiri dari 3 tahapan yakni pendefinisian (define), perancangan (design), dan pengembangan (develop). Pada tahap penyebaran (disseminate) tidak dilakukan, dimana tahap penyebaran (diseminate) perlu dilakukan uji coba lebih dari satu kali dengan subjek penelitian yang berbeda sedangkan penelitian ini hanya melakukan satu kali uji coba saja. Selain itu pula tujuan penelitian ini dapat diperoleh pada tahapan ketiga yakni pengembangan (develop). 


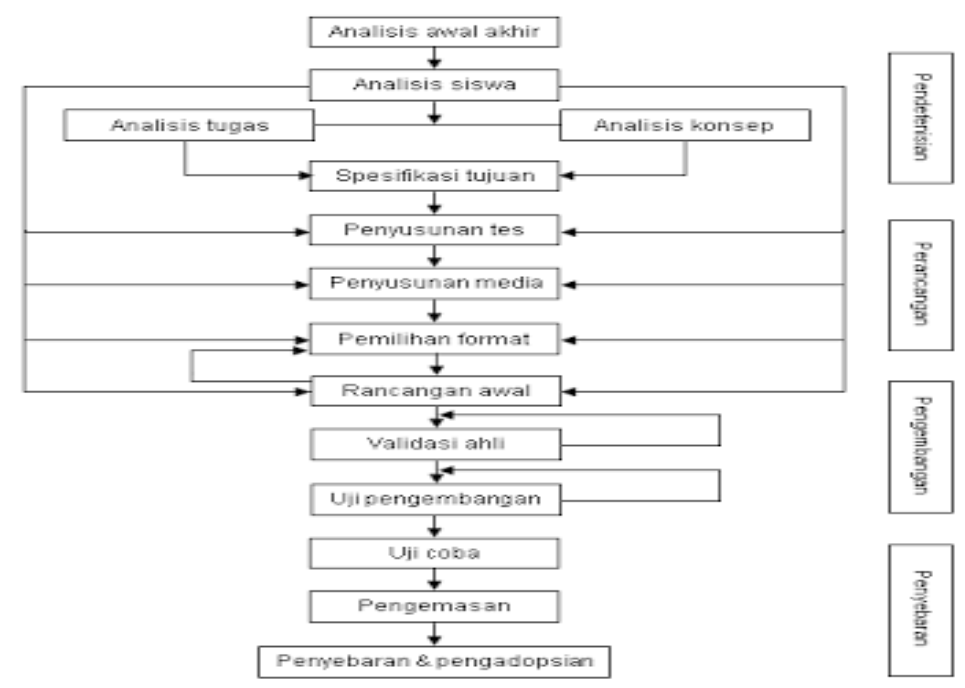

Gambar 1. Model Pengembangan 4-D

Teknik pengumpulan data yang digunakan adalah teknik komunikasi tidak langsung yaitu dengan menggunakan instrument lembar validasi dan angket. Lembar validasi digunakan untuk melihat kevalidan pocket book, sedangkan angket digunakan untuk melihat kepraktisan pocket book. Teknik analisis data yang digunakan untuk mengetahui kevalidan pocket book, data berupa skor (per butir) validasi ahli terhadap media pembelajaran yang diperoleh dalam bentuk kriteria skala Likert dan kriteria kualitatif yang disajikan pada table 1 dan 2 berikut.

Tabel 1. Kriteria Skor Menggunakan
\begin{tabular}{cc} 
Skala Likert \\
\hline Kriteria & Skor \\
\hline Sangat Baik & 5 \\
Baik & 4 \\
Cukup Baik & 3 \\
Kurang Baik & 2 \\
Tidak Baik & 1 \\
\hline & (Sumber: [4])
\end{tabular}

Tabel 2. Konversi ke dalam Bentuk Kualitatif

\begin{tabular}{cc}
\hline Kategori & Interval Skor \\
\hline Sangat Baik & $X>\bar{x}_{i}+1,5 S B_{i}$ \\
Baik & $\bar{x}_{i}+0,5 S B_{i}<X<\bar{x}_{i}+1,5 S B_{i}$ \\
Cukup Baik & $\bar{x}_{i}-0,5 S B_{i}<X<\bar{x}_{i}+0,5 S B_{i}$ \\
Kurang Baik & $\bar{x}_{i}-1,5 S B_{i}<X<\bar{x}_{i}-0,5 S B_{i}$ \\
Tidak Baik & $X \leq \bar{x}_{i}-1,5 S B_{i}$ \\
\hline
\end{tabular}

Keterangan:

$X=$ Total skor actual

$\bar{x}_{i}=$ Rata - rata skor ideal

$\bar{x}_{i}=\frac{1}{2}($ skor maks + skor $\min )$

$S B_{i}=$ Simpangan baku ideal

$S B_{i}=\frac{1}{6}($ skor maks - skor $\mathrm{min})$

Teknik analisis data yang digunakan untuk mengetahui kepraktisan pocket book ke dalam bentuk persentase kepraktisan. Kriteria persentase kepraktisan disajikan pada tabel 3 berikut. 
Tabel 3. Persentase Kepraktisan Produk

\begin{tabular}{cc}
\hline Persentase $(\%)$ & Kriteria Kepraktisan \\
\hline $80 \%<$ skor $\leq 100 \%$ & Sangat Praktis \\
$60 \%<$ skor $\leq 80 \%$ & Praktis \\
$40 \%<$ skor $\leq 60 \%$ & Cukup Praktis \\
$20 \%<$ skor $\leq 40 \%$ & Kurang Praktis \\
$0 \%<$ skor $\leq 20 \%$ & Tidak Praktis \\
\hline
\end{tabular}

Dalam penelitian ini, produk atau media pocket book dikatakan praktis apabila persentase yang diperoleh minimal tergolong cukup praktis.

\section{HASIL DAN PEMBAHASAN}

Pengembangan media pocket book ini menggunakan prosedur penelitian 4-D yang dikembangkan oleh Thiagarajan pada tahun 1974. Model ini terdiri dari 4 tahapan pengembangan yaitu, define, design, develop, dan desseminate atau diadaptasikan menjadi 4-P, yaitu Pendefinisian, Perancangan, Pengembangan, dan Penyebaran. Namun dengan beberapa pertimbangan oleh peneliti, tahapan yang digunakan sampai tahap pengembangan.

Tahap pertama dalam penelitian ini mecangkup analisis siswa dan analisis kebutuhan, sehingga diperoleh kesimpulan masalah apa saja yang didapatkan serta bagaimana solusinya. Tahap kedua melakukan perancangan, mulai dari merancang lembar instrumen penilaian atau angket, sampai dengan merancang pocket book. Angket yang dibuat berdasarkan aspek-aspek yang terdapat dalam BSNP 2007. Tahap ketiga dari validasi, pelaksanaan uji coba hingga perbaikan produk akhir.

Pocket book yang dirancang berbasis strategi discovery learning, dimana strategi tersebut sesuai dengan masalah yang dialami siswa yaitu kurangnya memiliki kemampuan pemahaman matematis. Pocket book terdiri dari sampul, kata pengantar, daftar isi, keterangan $\mathrm{KI}, \mathrm{KD}$, indikator pembelajaran, tujuan pembelajaran, materi, pendalaman materi, latihan soal, kata motivasi, dan daftar pustaka.

Validitas pocket book diperoleh nilai ratarata dari ketiga ahli adalah 277 tergolong kriteria valid dan kategori sangat baik. Yang kedua adalah uji coba terbatas, saat uji coba terbatas peneliti mendapatkan saran dari guru matematika untuk memvariasikan soal di dalam pocket book. Setelah itu, peneliti memasuki tahapan selanjutnya, yaitu uji coba lapangan. Uji coba lapangan dilakukan untuk melihat kepraktisan dari pocket book tersebut. Nilai kepraktisan dilihat dari nilai angket yang diisi guru dan seluruh siswa. Hasil perhitungan angket dari siswa dan guru diakumulasikan sehingga memperoleh persentase sebesar $82 \%$ dengan kriteria sangat praktis.

Penelitian ini sejalan dengan penelitian terdahulu yang berjudul pengembangan buku saku berbasis pendekatan CTL terhadap kemampuan berpikir kreatif siswa dalam materi kubus pada siswa kelas VIII MTs Sirajul Ulum Pontianak [9]. Media buku saku berbasis pendekatan CTL terhadap kemampuan berpikir kreatif siswa dalam materi kubus pada siswa kelas VIII MTs Sirajul Ulum Pontianak ini sangat valid, sangat praktis dan sangat efektif digunakan sebagai media pembelajaran. Tingkat kevalidan, kepraktisan, dan keefektifan buku saku berbasis pendekatan CTL sebagai media pembelajaran berdasarkan penilaian: (1) validator diperoleh rata-rata skor 64,33 dengan kategori sangat valid atau buku saku sangat layak digunakan, (2) angket siswa diperoleh rata-rata skor 43 dengan kategori sangat praktis, (3) angket guru diperoleh rata skor 46 dengan kategori sangat praktis. Penilaian keefektifan buku saku oleh siswa uji coba akhir memperoleh ketuntasan klasikal $100 \%$ dengan skor tugas pengerjaan buku saku sebear 70 dengan kategori sangat 
efektif dan skor posttest sebesar 45 dengan kategori sangat efektif

Dengan demikian apabila dibandingkan dengan penelitian tersebut, penelitian kali ini dapat mencapai tingkat keefektifan yang lebih tinggi yaitu rata-rata kevalidan 277 dengan kriteria sangat tinggi dan kepraktiasan mencapai $82 \%$ dengan kategori sangat praktis. Adapun pocket book yang telah diperbaiki antara lain:

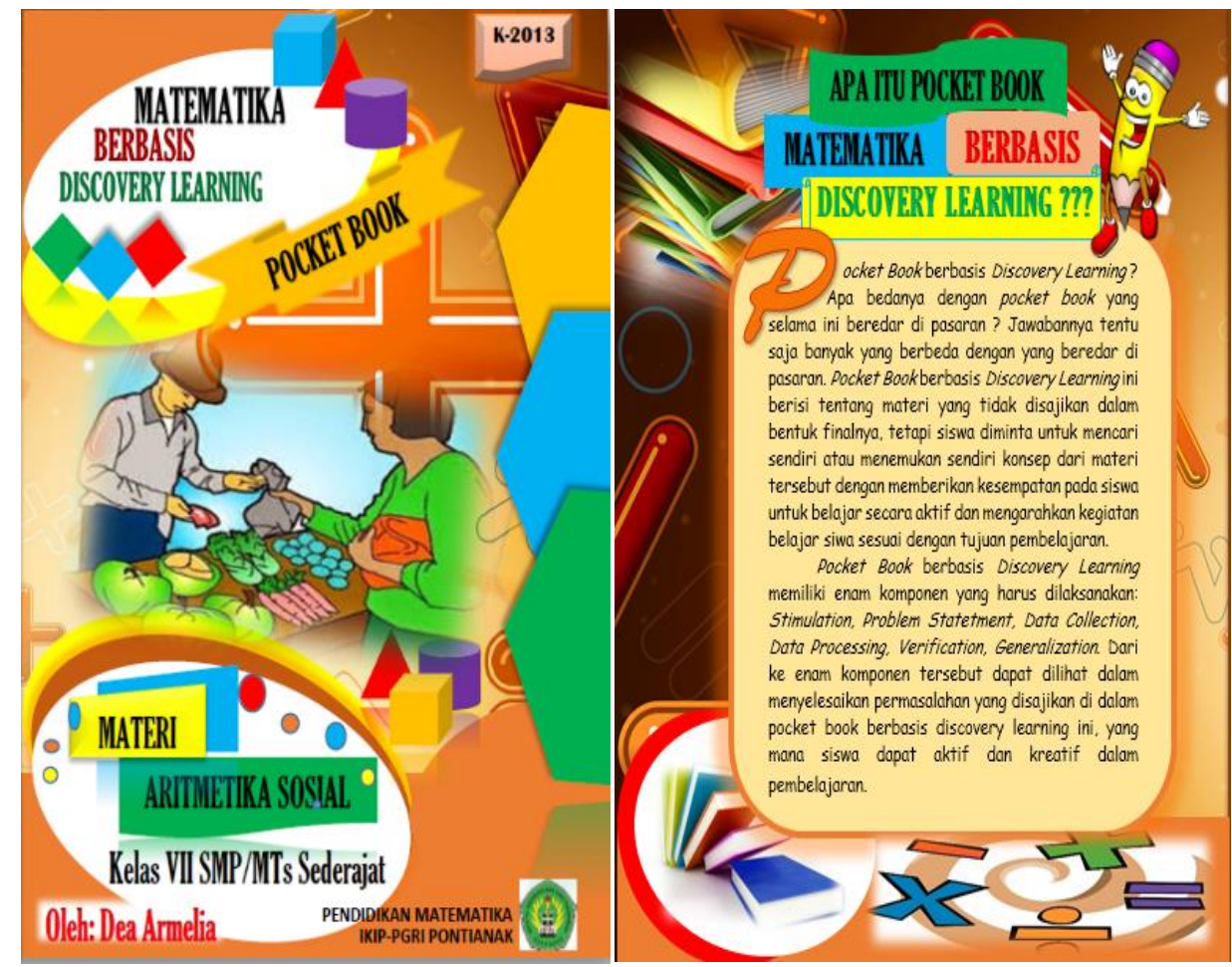

\section{Gambar 2. Sampul Depan dan Sampul Belakang Pocket Book}

\section{SIMPULAN}

Berdasarkan hasil pengembangan, penelitian, dan pembahasan terhadap media pocket book berbasis discovery learning terhadap kemampuan pemahaman matematis dapat simpulkan bahwa pengembangan media pocket book berbasis discovery learning terhadap kemampuan pemahaman matematis mencapai tingkat kevalidan dengan kategori sangat baik dan mencapai tingkat kepraktisan dengan kriteria sangat praktis.

\section{DAFTAR PUSTAKA}

[1] Hendriana, H., Rohaeti, E, E,. \& Sumarmo, U. Hard Skills dan Soft
Kills Matematik Siswa. Bandung: PT Refika Aditama. 2017

[2] Efendi, D. Pengembangan Bahan Ajar Matematika dengan Model Discovery Learning untuk Mengembangkan Keterampilan Berpikir Kritis Siswa Kelas VIII SMP Negeri 1 Seputih Agung. Tesis Universitas Negeri Lampung. 2016

[3] Hamdani. Strategi Belajar Mengajar. Bandung: Pustaka Setia. 2011

[4] Arsyad, A. Media Pembelajaran. Jakarta: PT. Raja Grafindo Persada. 2017

[5] Anggraeni, Y. Pengembangan Media Pembelajaran Berbentuk Pocket Book Untuk Meningkatkan Motivasi 
Belajar Siswa Pada Mata Pelajaran Praktik Akuntansi Manual (PAM) Kelas XI Akutansi SMK YPKK 1 Sleman Daerah Istemewa Yogyakarta: Universitas Negeri Yogyakarta. 2016

[6] Sugiyono. Metode Penelitian Kuantitatif, Kualitatif, dan $R \& D$. Bandung: Alfabeta. 2017

[7] Riduwan. Belajar Mudah Penelitian. Bandung: Alfabeta. 2015

[8] Agustyarini, Yhasinta, \& Jailani. Pengembangan Bahan Ajar
Matematika dengan Pendekatan Kontekstual dan Metode Penemuan Terbimbing untuk Meningkatkan EQ dan SQ Siswa SMP Eksalarasi. Jurnal Riset Pendidikan Matematika, Vol 2, No 1, pp: 135-147. 2015

[9] Winarti, P. Pengembangan Buku Saku Berbasis Pendekatan CTL terhadap Kemampuan Berpikir Kreatif Siswa dalam Materi Kubus pada Siswa Kelas VIII Mts Sirajul Ulum Pontianak. Skripsi IKIP PGRI Pontianak. 2017 